\title{
Enzymatic bioconversion of feather waste with keratinases of Bacillus cereus PCM 2849
}

\author{
Dominika P. Ciurko ${ }^{1}$, Wojciech Laba $^{1}$, Michał Piegza ${ }^{1}$, Piotr Juszczyk ${ }^{1}$, Anna Choińska-Pulit ${ }^{2}$, \\ Justyna Sobolczyk-Bednarek ${ }^{2}$
}

${ }^{1}$ Wroctaw University of Environmental and Life Sciences, Department of Biotechnology and Food Microbiology, Faculty of Biotechnology and Food Science, J. Chetmońskiego 37, 51-630 Wrocław; Poland 1

2"Poltegor-Institute”, Opencast Mining Institute, Parkowa 25, 51-616 Wrocław, Poland

"Corresponding author: e-mail: wojciech.laba@upwredu.pl

\begin{abstract}
Enzymatic preparation from culture of keratinolytic Bacillus cereus PCM 2849 was applied for hydrolysis of whole chicken feathers, after sulphitolytic pretreatment. This process was optimized using a three-factor Box-Behnken design, where the effect of substrate concentration, sulphite concentration during pretreatment and reaction temperature was evaluated on the release of amino acids. Obtained results revealed the highest impact of reaction temperature, followed by substrate content and sulphite during pretreatment. Optimal process conditions were established, i.e. temperature $44.4^{\circ} \mathrm{C}$, feathers $4.7 \%$ and treatment with $25.3 \mathrm{mM}$ sulphite. Amino acid composition of the obtained

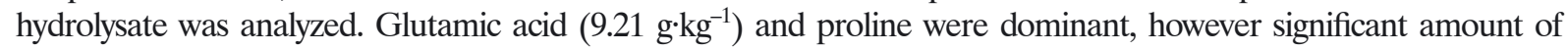
branched-chain amino acids was also observed. The FTIR analysis of residual substrate revealed the cleavage of disulphide bonds in keratin through the presence of thioester residues. The absence of reduced cysteine residues was confirmed, along with minor changes in proportions of keratin substructures.
\end{abstract}

Keywords: feather waste, Bacillus cereus, Box-Behnken design, hydrolysis, thermo-chemical pretreatment.

\section{INTRODUCTION}

Poultry production is incessantly a vital branch of meat industry. Regrettably, the constantly growing supply of poultry meat is inseparable from the increased stream of organic by-products, generated in the form of viscera, feet, heads, bones, blood, and feathers ${ }^{1}$. Chicken feather waste, due to the large scale of meat production and highly resilient characteristics, poses a serious environmental problem. As estimated from the data from the Food and Agriculture Organization of the United Nations (FAO), in 2018 nearly 9 million tons of feathers were produced. Therefore, leading poultry meat producers, i.e. the Unites States of America, China, the European Union and Brazil search for effective methods of poultry waste management ${ }^{2}$.

Feather waste is considered as a potential protein source due to the high content of keratins, exceeding $90 \%\left(\mathrm{w} \mathrm{w}^{-1}\right)^{3}$. Furthermore, feathers are perceived as the source of the major amino acid like serine $(16 \%)$, proline $(12 \%)$, glycine $(11 \%)$, valine $(9 \%)$ and cysteine (7\%), recognized as the dominant amino acids of this protein $^{4}$. Amino acids with a neutral (glycine, alanine, phenylalanine, leucine, isoleucine, valine and proline), hydrophobic (tyrosine, serine and threonine), acid (aspartic and glutamic acid) and alkaline (lysine, arginine, histidine and tryptophan) properties appear in reduced quantities, but their extraction is still possible ${ }^{5}$.

Despite keratin proteins are insoluble ${ }^{3}$, their solubility can be improved, but it requires alkalinization, acidification, elevated temperature or participation of a reducing agent, like $\mathrm{Na}_{2} \mathrm{SO}_{3}$ or $\mathrm{Na}_{2} \mathrm{~S}^{6}$.

The most typical route for feather waste management is the conversion into feather meal. Unfortunately, the production process involves steam treatment and entails a number of drawbacks, i.e. destruction of certain essential amino acids, such as methionine, lysine and tryptophan, formation of non-nutritive amino acids (lysinoalanine, lanthionine), and overall poor digestibility ${ }^{7}$.
In order to avoid negative impact of heat treatment on protein quality, new technologies are sought after. The alternative, more beneficial method is hydrolysis conducted by active microbial cells. Feather degradation may be carry out using purified keratinolytic enzymes or directly in microbial cultures. Keratinases are produced by certain fungi, actinomycetes, and bacteria. Dermatophytic fungi, isolated from human and animal injuries, such as Microsporum sp., Trychophyton sp. and Doratomyces microsporum, have been thoroughly described. Moreover, several bacteria belonging to genera Bacillus (B. licheniformis, B. subtilis, B. pumilus, B. cereus) and Streptomyces (S. pactum, S. albidoflavus K1-02, S. griseus) are capable of using keratin as the sole nutrient source ${ }^{8}$. Nevertheless, optimization of process conditions is essential for efficient hydrolysis of the feather waste.

As many authors previously reported, the effect of the physical conditions on the feather proteolysis is critical. The impact of $\mathrm{pH}$, temperature, medium composition, culture rotation speed on the keratin degradation were repeatedly investigated in order to understand the nature of the process. Result of many studies pointed to alkaline $\mathrm{pH}$ values, as optimal for keratinolytic enzymes action, ${ }^{90}$. Furthermore, most of keratin-degrading peptidases are stable in a broad $\mathrm{pH}$ range, as shown in a number of reports, ${ }^{91}$. The initial $\mathrm{pH}$ of the medium also affected microbial growth and thus effectivity of feather degradation and keratinase production ${ }^{10,12,13}$.

Some research focused on the role of rotation speed for the feather degradation in bacterial cultures, as low rotation speed leads to reduction of the enzyme production as a result of poor oxygen distribution. Excessive agitation may, however, lead to cell degradation or enzyme denaturation, and as a result, to decreased efficiency of proteolysis ${ }^{10,13}$.

The impact of the temperature on the keratin degrading enzyme was widely studied as one of the most important parameter that affects feather degradation. A majority 
of keratinase-producing bacteria are mesophilic species and grow well within the temperature range of $30-40^{\circ} \mathrm{C}$, whereas the optimum temperature for the activity of keratinases falls in the range of $50-60^{\circ} \mathrm{C}$. However, keratin degrading enzymes are stable in a board temperature range, but the presence of $\mathrm{Ca}^{2+}$ cations is emphasized by some authors as indispensable ${ }^{9,10,13}$.

Numerous studies were conducted in order to investigate the impact of medium composition on the efficiency of feather protein solubilization and resultant amino acids extraction. High concentrations of the keratinous substrate may cause substrate inhibition or repression of keratinase production, while low concentrations may not support microbial growth or enzyme induction ${ }^{\mathbf{1 4}}$. Whereas the concentration of feathers is one of the most important factors that affect their solubilization, the addition of a supplementary source of carbon and nitrogen often suppresses the process, due to e.g. catabolite repression. In fact, the need for adjustment of medium composition with carbohydrates or inorganic nitrogen is a microorganism-specific feature ${ }^{\mathbf{1 5}}$.

Development of enzymatic and microbiological methods for the feather hydrolysis to soluble proteins and amino acids is essential for future management, offering low cost and energy-saving operation. One of the prospective key applications could be the use of feather waste as a semi-slow-release nitrogen fertilizer. However, in a view of specific keratin structure, its rapid decomposition conducted by soil microorganisms is restrained. Therefore, in order to increase the mineralization rate and decrease the fertilizer production costs keratin is preliminarily hydrolyzed ${ }^{\mathbf{1 6}, 17}$.

In this paper, we report the results of enzymatic hydrolysis of chicken feathers with the application of a proteolytic preparation from culture of a keratinolytic bacterium Bacillus cereus PCM 2849. To improve the efficiency of hydrolysis, sulphitolytic pretreatment of the keratinous substrate was applied. To describe the combined effect of three independent variables, such as chicken feathers content, sulphite concentration during pretreatment and reaction temperature, a Box-Behnken experimental design was employed. An increase of concentration of free amino groups was expected as a measure of effective keratin hydrolysis.

\section{MATERIAL AND METHODS}

\section{Bacterial strain and crude enzyme preparation}

Keratinolytic bacteria used in this study, Bacillus cereus PCM2849 were previously isolated from pig bristle waste and deposited in Polish Collection of Microorganisms at the Institute of Immunology and Experimental Therapy in Wrocław.

Enzyme production was carried out by cultivation of bacteria in an agitated incubator (180 r.p.m.) in $250 \mathrm{ml}$ Erlenmeyer flasks containing $50 \mathrm{ml}$ of feather medium, for $36 \mathrm{~h}$ at $30^{\circ} \mathrm{C}$. Feather medium was composed of $\left(\mathrm{g} \mathrm{l}^{-1}\right)$ : feathers (10.0), $\mathrm{MgSO}_{4}(1.0), \mathrm{KH}_{2} \mathrm{PO}_{4}(0.1)$, $\mathrm{CaCl}_{2}(0.1), \mathrm{FeSO}_{4}(0.01)$, initial pH 7.1. A 24h culture in Luria-Bertani (LB) broth, composed of $\left(\mathrm{g} \mathrm{l}^{-1}\right)$ : yeast extract (0.5), tryptone (1.0), $\mathrm{NaCl}(1.0)$, served as inoculum, at $0.5 \mathrm{ml}$ per flaks.
After cultivation, residual feathers were removed and culture fluid was centrifuged (12 $000 \mathrm{rpm}$ for $10 \mathrm{~min}$ at $\left.4^{\circ} \mathrm{C}\right)$. Cell-free supernatant was concentrated by ultrafiltration using the Labscale ${ }^{\mathrm{TM}}$ TFT System (Millipore) with a Pellicon XL 50 cassette, Ultracel-10 PLCGC membrane (10 kDa cut-off). The obtained preparation was stored in portions at $-24^{\circ} \mathrm{C}$.

\section{Preparation of feathers}

White broiler chicken feathers, provided by a local poultry-processing plant (Wrocław, Poland), were initially washed with running tap water and distilled water, airdried and strewn into flasks.

Prior to hydrolysis, feathers were subjected to a thermo-chemical pretreatment. This procedure was performed by autoclaving $\left(20 \mathrm{~min}, 121^{\circ} \mathrm{C}\right)$ feathers suspended in sodium sulphite solution (Sigma-Aldrich) at suited concentrations $(10 \mathrm{mM}, 65 \mathrm{mM}, 120 \mathrm{Mm})$. The proportion of feathers in the solution was $10.0 \mathrm{~g} \cdot \mathrm{l}^{-1}$. After the pretreatment feathers were separated by filtration, washed several times with tap and distilled water and dried at room temperature.

\section{Optimization of feather hydrolysis using a Box-Behnken design}

In order to optimize the hydrolysis of chicken feathers with crude keratinase of B. cereus PCM 2849, the effect of selected reaction conditions was modeled using a three-factor Box-Behnken experimental design. The influence of feather content $\left(\mathrm{X}_{1}\right)$, reaction temperature $\left(\mathrm{X}_{2}\right)$ and sodium sulphite concentration during substrate pretreatment $\left(\mathrm{X}_{3}\right)$ were studied. The release of free amino groups from the hydrolyzed substrate was the measured response (dependent variable).

Feather hydrolysis was conducted in $10 \mathrm{ml}$ reaction mixtures containing: crude enzyme preparation (33U), $0.05 \mathrm{M}$ Tris- $\mathrm{HCl}$ buffer $\mathrm{pH} 7.5, \mathrm{CaCl}_{2}(2 \mathrm{mM})$, and pretreated feathers at concentration $1 \%, 3 \%$ and $5 \%$. The reaction was carried out for $24 \mathrm{~h}$ at $55^{\circ} \mathrm{C}$. Constant enzyme dose was maintained. The amount of free amino groups in hydrolyzed samples were measured using a ninhydrin method ${ }^{18}$ and tabulated. Glycine served as a standard for preparation of a calibration curve.

Experimental levels of each independent variable, selected in accordance with previous research ${ }^{19}$, are presented in Table 1. The model incorporated execution of the central point of the experiment in triplicate ${ }^{19}$. Each experimental value represents a mean of two independent determinations. Experimental data was analyzed after decimal logarithm transformation. Predicted and actual values of the dependent independent variable, determined in the study are presented in Table 2.

The relationship between independent variables and the response was based on the polynomial equation (Eq. 1). $Y=\beta_{0}+\beta_{1} X_{1}+\beta_{2} X_{2}+\beta_{3} X_{3}+\beta_{11} X_{1} X_{1}+\beta_{22} X_{2} X_{2}+$ $\beta_{33} X_{3} X_{3}+\beta_{12} X_{1} X_{2}+\beta_{13} X_{1} X_{3}+\beta_{23} X_{2} X_{3}(1)$

In the presented equation $Y$ represents the predicted response, $\beta_{0}$ is the intercept, $\beta_{1}, \beta_{2}, \beta_{3}$ are the linear regression coefficients, $\beta_{11}, \beta_{22}, \beta_{33}$ are the quadratic regression coefficients, and $\beta_{12}, \beta_{23}, \beta_{13}$ are the interaction terms. The $\mathrm{X}_{1}, \mathrm{X}_{2}$ and $\mathrm{X}_{3}$ represent the independent variables: 
Table 1. Experimental levels of independent variables

\begin{tabular}{|c|c|c|c|c|}
\hline \multirow[b]{2}{*}{ Variables } & \multicolumn{4}{|c|}{ Range and levels } \\
\hline & $\begin{array}{c}\text { Low level } \\
(-1)\end{array}$ & $\begin{array}{c}\text { Center level } \\
(0)\end{array}$ & $\begin{array}{l}\text { High level } \\
(+1)\end{array}$ & $\Delta \mathrm{X}$ \\
\hline Feather content [\%] $(\mathrm{X})$ & 1 & 3 & 5 & 4.67 \\
\hline Reaction temperature $[\mathrm{C}]\left(\mathrm{X}_{2}\right)$ & 35 & 45 & 55 & 44.4 \\
\hline $\begin{array}{l}\text { Sodium sulphite concentration during substrate } \\
\text { pretreatment }\left[\mathrm{mmol} \mathrm{I}^{-1}\right]\left(\mathrm{X}_{3}\right)\end{array}$ & 10 & 65 & 120 & 25.28 \\
\hline
\end{tabular}

$\Delta \mathrm{X}$ - optimum level of each independent variable

Table 2. Experimental Box-Behnken design structure with the independent variables: $\mathrm{X}_{1}-$ feather content [\%], $\mathrm{X}_{2}$ - reaction temperature $\left[{ }^{\circ} \mathrm{C}\right], \mathrm{X}_{3}$ - sulphite concentration during substrate pretreatment $[\mathrm{mM}]$ and obtained results

\begin{tabular}{|c|c|c|c|c|c|}
\hline & \multicolumn{3}{|c|}{ Independent variables } & \multicolumn{2}{|c|}{$\begin{array}{c}\text { Dependent variable } \\
{\left[\log _{10}(\text { a.a. mM) }]\right.}\end{array}$} \\
\hline $\begin{array}{l}r \\
u \\
\text { u }\end{array}$ & $X_{1}$ & $\mathrm{X}_{2}$ & $\mathrm{X}_{3}$ & $\begin{array}{l}\text { actual } \\
\text { value }\end{array}$ & $\begin{array}{l}\text { predicted } \\
\text { value }\end{array}$ \\
\hline 1 & 1 & 35 & 65 & 1.2698 & 1.2511 \\
\hline 2 & 5 & 35 & 65 & 1.8870 & 2.0988 \\
\hline 3 & 1 & 55 & 65 & 1.3220 & 1.1102 \\
\hline 4 & 5 & 55 & 65 & 1.0490 & 1.0677 \\
\hline 5 & 1 & 45 & 10 & 0.8087 & 1.0617 \\
\hline 6 & 5 & 45 & 10 & 2.0533 & 2.0759 \\
\hline 7 & 1 & 45 & 120 & 1.9984 & 1.9758 \\
\hline 8 & 5 & 45 & 120 & 2.0198 & 1.7668 \\
\hline 9 & 3 & 35 & 10 & 1.8010 & 1.5667 \\
\hline $\begin{array}{l}1 \\
0\end{array}$ & 3 & 55 & 10 & 0.6083 & 0.5670 \\
\hline $\begin{array}{l}1 \\
1 \\
\end{array}$ & 3 & 35 & 120 & 1.4142 & 1.4555 \\
\hline $\begin{array}{l}1 \\
2\end{array}$ & 3 & 55 & 120 & 1.0488 & 1.2832 \\
\hline $\begin{array}{l}1 \\
3 \\
\end{array}$ & 3 & 45 & 65 & 1.9411 & 1.9189 \\
\hline $\begin{array}{l}1 \\
4\end{array}$ & 3 & 45 & 65 & 1.8271 & 1.9189 \\
\hline $\begin{array}{l}1 \\
5\end{array}$ & 3 & 45 & 65 & 1.9885 & 1.9189 \\
\hline
\end{tabular}

$\mathrm{X}_{1}$ - feather content [\%],

$\mathrm{X}_{2}$ - reaction temperature $\left[{ }^{\circ} \mathrm{C}\right]$.

$\mathrm{X}_{3}$ - sodium sulphite concentration during substrate pretreatment $[\mathrm{mM}]$.

Analysis of variance (ANOVA) was performed to determine the significance of the model, and Student's $\mathrm{t}$-test and $\mathrm{p}$-values were used to evaluate the significance of individual regression coefficients. An alpha $(\alpha)$ level of 0.05 was used to establish the statistical significance.

Finally, in order to illustrate the relationship between independent variables and the response, three-dimensional response surface plots were prepared, constructed by plotting the response on the Z-axis against any two independent variables, assuming the central level of third variable. Data analysis from the Box-Behnken design was performed using Statistica 13 (StatSoft Inc).

\section{Feather hydrolysis in optimal conditions}

In order to evaluate the quality of the obtained model and to achieve the maximum degree of feather keratin hydrolysis, the process was run according to the established optimal conditions. For this purpose, feather substrate was pretreated using $25.28 \mathrm{mM}$ sulphite solution and subsequent hydrolysis was carried out at $44.4^{\circ} \mathrm{C}$. The hydrolysis was run for $24 \mathrm{~h}$ in 0.11 Erlenmeyer flasks, containing $10 \mathrm{ml}$ of a reaction mixture, composed of: of $46.7 \mathrm{~g}^{-1}$ feathers in $0.05 \mathrm{M}$ Tris- $\mathrm{HCl}$ buffer $\mathrm{pH}=7.5$ containing $\mathrm{CaCl}_{2}(2 \mathrm{mM})$ and a proper enzyme dose. Additionally, to investigate the influence of the enzyme concentration on the release of hydrolysis products, the crude enzyme was applied at various amounts: $33 \mathrm{U}, 50 \mathrm{U}$, 100U, 250U. Finally, concentration and composition of amino acids in the obtained samples were analyzed.

\section{Determination of proteolytic activity}

Proteolytic activity of the enzymatic preparation was determined with a modified method of Anson. Casein solution $\left(11.0 \mathrm{~g} \cdot \mathrm{l}^{-1}\right)$ was prepared in the Tris- $\mathrm{HCl}$ buffer $(\mathrm{pH}=7.5)$ and served as a substrate in the enzymatic reaction. The reaction mixture contained $0.9 \mathrm{ml}$ of casein solution and $0.1 \mathrm{ml}$ of properly diluted enzyme. Proteolysis was conducted for $10 \mathrm{~min}$ at $55^{\circ} \mathrm{C}$ and was terminated by an addition of $8 \%$ trichloroacetic acid (TCA) (1.0). Finally samples were centrifuged (12000 $\mathrm{rpm}, 15 \mathrm{~min}$ ) to separate protein precipitate. Absorbance of supernatants (containing products of protein hydrolysis) was determined against a control (enzyme added after TCA) at $280 \mathrm{~nm}$ wavelength. Tyrosine solution (Sigma-Aldrich) served as a standard for preparation of a calibration curve. One unit of enzyme activity was defined as the amount of enzyme required to liberate $1 \mu \mathrm{mol}$ of tyrosine per $1 \mathrm{ml}$ of culture fluid within 1 min, under the experimental conditions.

\section{Amino acid composition of hydrolyzed keratin samples}

Amino acid composition of feather hydrolysates obtained in optimal reaction conditions determined using the amino acid analyzer AAA400 INGOS after derivatization of amino acids. The first step was the separation on an ion-exchange column, followed by the detection of amino acids in the effluent with a ninhydrin reagent. Finally absorbance of the samples were measured against a control at 440 and $570 \mathrm{~nm}$.

\section{Fourier-transform infrared spectroscopy(FTIR)}

Structural changes in raw chicken feathers, feathers after pretreatment and enzymatic hydrolysis were analyzed by Fourier transform infrared spectroscopy (FTIR). Crude feather were used as a control sample. Measurements were performed on the VERTEX 70 spectrometer with a dedicated software for Fourier transformation. Specimens were prepared as $\mathrm{KBr}$ pellets. Measurements were recorded within the $4000-400 \mathrm{~cm}^{-1}$ range with $2 \mathrm{~cm}^{-1}$ resolution. 


\section{RESULTS AND DISCUSSION}

\section{Optimization of feather hydrolysis with a Box-Benkhen design}

The obtained concentrated enzymatic preparation from culture of $B$. cereus PCM 2849 exhibited proteolytic activity of $507.5 \pm 10.6 \mathrm{U}\left(3905 \mathrm{U} \mathrm{mg}^{-1}\right)$, and was used during subsequent stages of the study.

The experimental design according to Box-Benkhen was performed, where amino acids concentration in hydrolyzed samples was a measure of the dependent variable. For each tested independent factor, i.e. substrate concentration, sulphite concentration during pretreatment and reaction temperature, the impact on the amino acid concentration was established. The following polynomial equation was generated by applying multiple regression analysis on the design matrix, to describe the model (significant terms underlined) (Eq. 2).

$\mathrm{Y}=-9.000+0.808 \mathrm{X}_{1}+0.447 \mathrm{X}_{2}+0.002 \mathrm{X}_{3}-$ $0.004 X_{1} X_{1}-0.005 X_{2} X_{2}-0.000 X_{3} X_{3}-0.011 X_{1} X_{2}-$ $0.003 \mathrm{X}_{1} \mathrm{X}_{3}+0.000 \mathrm{X}_{2} \mathrm{X}_{3}(2)$.

The quality of the obtained model was evaluated with ANOVA. The Fisher's F-test showed the significance of the regression model, as the calculated Fvalue $\left(\mathrm{F}_{\mathrm{cal}}=4.82\right)$ was higher than the tabulated value $\left(F_{t a b}=4.77\right)$ at the $p-$ value of 0.05 . The ratio of these two parameters, presented in Table 3 , confirmed the relevance of the model.

Table 3. Analysis of variance (ANOVA) for the obtained regression model

\begin{tabular}{|l|c|c|c|c|c|}
\hline $\begin{array}{l}\text { Error } \\
\text { source }\end{array}$ & $\begin{array}{c}\text { Sum of } \\
\text { squares } \\
\text { [SS] }\end{array}$ & $\begin{array}{c}\text { Degrees } \\
\text { of } \\
\text { freedom } \\
\text { [DF] }\end{array}$ & $\begin{array}{c}\text { Mean } \\
\text { square } \\
\text { [MS] }\end{array}$ & $\begin{array}{c}\text { F- } \\
\text { value }\end{array}$ & $\begin{array}{c}\text { P- } \\
\text { value }\end{array}$ \\
\hline $\begin{array}{l}\text { Regression } \\
\text { model }\end{array}$ & 3.0117 & 9 & 0.3346 & 4.82 & $<0.05$ \\
\hline $\begin{array}{l}\text { Residual } \\
\text { error }\end{array}$ & 0.3465 & 5 & 0.0693 & - & - \\
\hline Lack of fit & 0.3327 & 3 & 0.1109 & 16.12 & 0.0590 \\
\hline Pure error & 0.0138 & 2 & 0.0069 & - & - \\
\hline Cor. total & 3.3583 & 14 & & - & - \\
\hline
\end{tabular}

$\mathrm{R}^{2}=0.8968, \mathrm{R}^{2} \mathrm{adj} .=0.7111$

The coefficient of determination $\left(\mathrm{R}^{2}\right)$ was used to establish the fit of the model to experimental data and takes values between 0 and 1 . When the $\mathrm{R}^{2}$ approximates to 1 , the model can predict a response with very high accuracy ${ }^{\mathbf{2 0}}$. In the presented study, the $\mathrm{R}^{2}$ reached 0.8968 , so that over $89 \%$ of the variability in the response can be explained by the regression model and the rest is due to noise. The adjusted coefficient of determination $\left(\mathrm{R}_{\text {adj }}^{2}\right)$ was relatively high $(0.7111)$, which additionally pointed to good correlation between the experimental and the predicted values.

To determine the significance of each coefficient, Student's t-test was applied. It allowed to determine the pattern of interactions between the tested independent variables. In this research, majority of model terms exerted statistically significant influence on the concentration of amino acids, as shown in Table 4. Only quadratic effects of feather content $\left(\mathrm{X}_{1} \mathrm{X}_{1}\right)$ (t-value $=0.4058$, $\mathrm{p}=0.7242)$ and sodium sulphite concentration $\left(\mathrm{X}_{3} \mathrm{X}_{3}\right)$
Table 4. Effect results of the Box-Behnken design

\begin{tabular}{|l|c|c|c|c|}
\hline Variable & Coefficient & Standard error & T-value & P-value \\
\cline { 2 - 5 } intercept & 1.4400 & 0.0239 & 60.1464 & 0.0003 \\
\hline $\mathrm{X}_{1}$ & 0.4026 & 0.0586 & 6.8648 & 0.0206 \\
\hline $\mathrm{X}_{2}$ & -0.5860 & 0.0586 & -9.9921 & 0.0099 \\
\hline $\mathrm{X}_{3}$ & 0.3025 & 0.0586 & 5.1579 & 0.0356 \\
\hline $\mathrm{X}_{1} \mathrm{X}_{1}$ & 0.0175 & 0.0432 & 0.4058 & 0.7242 \\
\hline $\mathrm{X}_{2} \mathrm{X}_{2}$ & 0.5195 & 0.0432 & 12.0349 & 0.0068 \\
\hline $\mathrm{X}_{3} \mathrm{X}_{3}$ & 0.1814 & 0.0432 & 4.2018 & 0.0522 \\
\hline $\mathrm{X}_{1} \mathrm{X}_{2}$ & -0.4451 & 0.0829 & -5.3673 & 0.0330 \\
\hline $\mathrm{X}_{1} \mathrm{X}_{3}$ & -0.6116 & 0.0829 & -7.3744 & 0.0179 \\
\hline $\mathrm{X}_{2} \mathrm{X}_{3}$ & 0.4137 & 0.0829 & 4.9877 & 0.0379 \\
\hline
\end{tabular}

p-values $<0.05$ were considered as significant

$(\mathrm{t}$-value $=4.2018, \mathrm{p}=0.0522)$ had an irrelevant influence $(\mathrm{p}>0.05)$.

The linear effect of temperature $\left(X_{2}\right)(t$-value $=9.9921$, $\mathrm{p}=0.0099)$ and quadratic effect of temperature $\left(\mathrm{X}_{2} \mathrm{X}_{2}\right)$ ( $\mathrm{t}$-value $=12.0349, \mathrm{p}=0.0068)$ were the most significant coefficients, that strongly affected the hydrolysis process. This result pointed to temperature of the hydrolysis $\left(\mathrm{X}_{2}\right)$ as the most influential reaction condition. The significance of each analyzed coefficient is presented in Table 4 .

Three-dimensional response surface plots were prepared to illustrate the combined effect of independent variables on the measured response. The simultaneous effect of the reaction temperature $\left(\mathrm{X}_{2}\right)$ on the concentration of amino acids is depicted in the Fig. 1a and Fig. 1b. At optimum temperature $44.4^{\circ} \mathrm{C}$ the concentration of hydrolysis products was high but any substantial deviation caused its steep decline. The linear impact of feather concentration $\left(\mathrm{X}_{1}\right)$ on the measured response is visible in the Fig. 1a and Fig. 1c. Increasing feather concentration caused a proportional increase of the amino acids content in the hydrolyzed samples. However, proteinaceous substrate must be applied within a certain concentration range. According to Eslahiet al. ${ }^{\mathbf{2 1}}$, who examined the influence of substrate concentration on the process of proteolysis, and what follows, for the resultant keratin nanoparticles size, excessive substrate content could contribute to a decreased hydrolysis yield. This might be a result of an inhibitory effect of hydrolysis products, enzyme inactivation and a decrease in substrate reactivity. Among tested feather concentrations (50 $\mathrm{g} \cdot \mathrm{l}^{-1}, 150 \mathrm{~g} \cdot \mathrm{l}^{-1}, 250 \mathrm{~g} \cdot \mathrm{l}^{-1}$ ) the optimal value for the proper proteolysis was $50 \mathrm{~g} \cdot \mathrm{l}^{-1}$, which is in accordance with results obtained in own research.

Moreover, the impact of sulphite pretreatment $\left(\mathrm{X}_{3}\right)$ on the amino acid release was dependent on feather concentration $\left(\mathrm{X}_{1}\right)$, as a statistically significant interaction was confirmed (Fig.1c). In the present study, sulphitolytic action was used to loosen tightly packed keratin structure and hence, improve amino acid release efficiency. The obtained results confirmed capability of this process, through increased degree of the substrate decomposition. In addition, the remaining interactions $\left(\mathrm{X}_{1} \mathrm{X}_{2}\right.$ and $\left.\mathrm{X}_{2} \mathrm{X}_{3}\right)$ were also established as relevant. The highest impact on the hydrolysis efficiency was due to the mutual effect of feather content $\left(\mathrm{X}_{1}\right)$ and sodium sulphite concentration $\left(\mathrm{X}_{3}\right)$.

Analysis of the obtained model allowed to calculate the maximum predicted concentration of amino acids at $125.55 \mathrm{mM}\left(\log _{10}\right.$ [a.a. $\left.\left.\mathrm{mM}\right]=2.0988\right)$, while the 


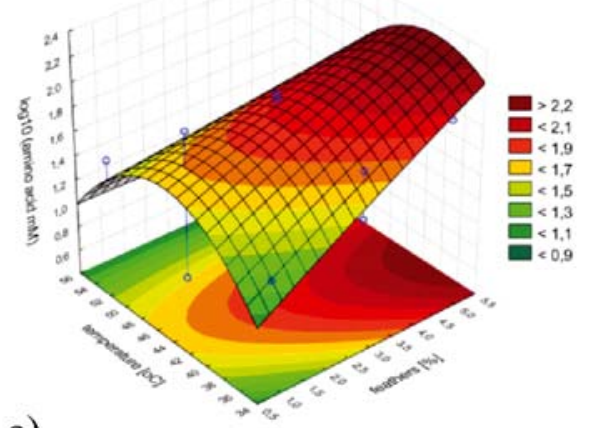

a)

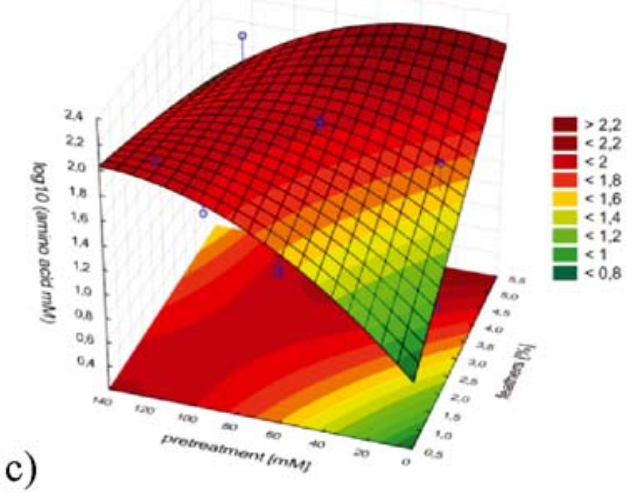

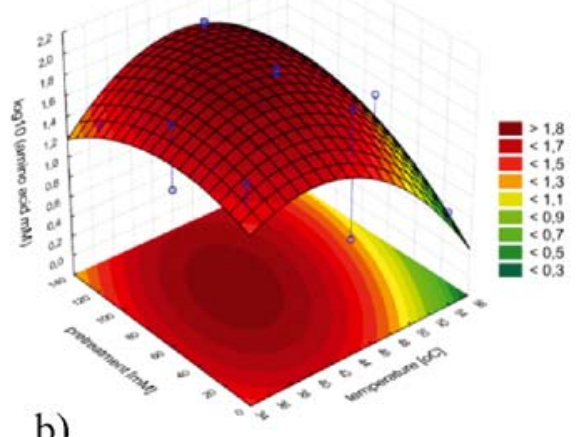

b)

Figure 1. Response surface plot depicting the impact of tested variables on the release of amino acids: a) the effect of reaction temperature $\left[{ }^{\circ} \mathrm{C}\right]$ and substrate concentration $[\%]$, b) reaction temperature $\left[{ }^{\circ} \mathrm{C}\right]$ and sulphite concentration $\left.[\mathrm{mM}], \mathrm{c}\right)$ substrate concentration $[\%]$ and sulphite concentration $[\mathrm{mM}]$.

corresponding experimental level was $77.09 \mathrm{Mm}\left(\log _{10}\right.$ [a.a. $\mathrm{mM}]=1.8870$ ).

\section{Hydrolysis of feathers in optimal conditions}

The obtained regression model allowed to determine the most advantageous reaction conditions, according to which the hydrolysis was conducted. The optimum feather content was established at the level $4.67 \%$, while the reaction temperature and sodium sulphite concentration during substrate pretreatment were $44.4^{\circ} \mathrm{C}$ and $25.28 \mathrm{mM}$, respectively (Table 1).

Effective feather waste management is not limited to methods based on enzymatic hydrolysis. Keratin degradation within bacterial cultures are considered equally or even more efficient. Kumar et al. ${ }^{22}$ evaluated the effect of feather concentration (15-60 g. $\left.\mathrm{l}^{-1}\right)$ and initial $\mathrm{pH}$ (6-11) on the production of amino acids and soluble proteins in Bacillus sp. MPTK6 cultures. In contrast to own research, the highest accumulation of amino acids was obtained in media containing $30 \mathrm{~g} \cdot \mathrm{l}^{-1}$ feathers $(506 \pm 16 \mathrm{mM})$. Concentration of the substrate at 15 $\mathrm{g} \cdot \mathrm{l}^{-1}, 45 \mathrm{~g} \cdot \mathrm{l}^{-1}$ or $60 \mathrm{~g} \cdot \mathrm{l}^{-1}$ caused a decline of degradation products to $190 \mathrm{mM}, 400 \mathrm{mM}$ and $373 \mathrm{mM}$, respectively. In our study, further increment of enzyme dose allowed to increase the accumulation of free amino acids, to $119.9 \mathrm{mM}$ at maximum, in the reaction conducted with $250 \mathrm{U}$ of enzyme.

Laba et al. ${ }^{23}$ carried out optimization of the chicken feather decomposition in cultures of keratinolytic bacteria Kocuria rhizophila PCM 2931. This research was performed in order to maximize accumulation of proteins and amino acids using a Plackett-Burman and a Box-
Behnken design. Feather content was the most influential variable that affected accumulation of hydrolysis products in the culture fluid. The concentration $43 \mathrm{~g} \cdot \mathrm{l}^{-1}$ was determined as the optimal. The maximum amino acids accumulation yielded in optimal conditions was higher than in own research and reached $167.31 \mathrm{mM}$. However, the route of keratin biodegradation in bacterial cultures is obviously different, as compared to enzymatic hydrolysis. The presence of living cells is not only connected with biosynthesis of proteolytic enzymes, but also provides a proper red-ox potential and a constant supply of cofactors for membrane-bound disulfide reductases.

FTIR spectroscopy of native, pretreated and hydrolyzed feathers

Native chicken feathers, pretreated feathers and residual material after hydrolysis were subjected to FTIR analysis to demonstrate substructural changes in the keratinous substrate (Fig. 2). The occurrence of a small convexity at $1040 \mathrm{~cm}^{-1}$ after substrate pretreatment could be an evidence of a sulphitolytic effect to take place, as a result of Bunte salt formation, manifested by $\mathrm{S}-\mathrm{O}$ symmetric stretching vibrations ${ }^{24}$. This signal was absent in the enzyme-treated material, suggesting that the hydrolysate was free of thioester residues (Fig. 3).

Unlike in the report of Paul et al. ${ }^{25}$, no significant signal from stretching S-H bonds vibration was observed at $2560 \mathrm{~cm}^{-1}$, implying that no major amounts of reduced thiols were present in pretreated feathers or substrate. That was presumably a result of sulphitolytic treatment that occupied majority of available cysteine residues by S-sulphocysteine. 


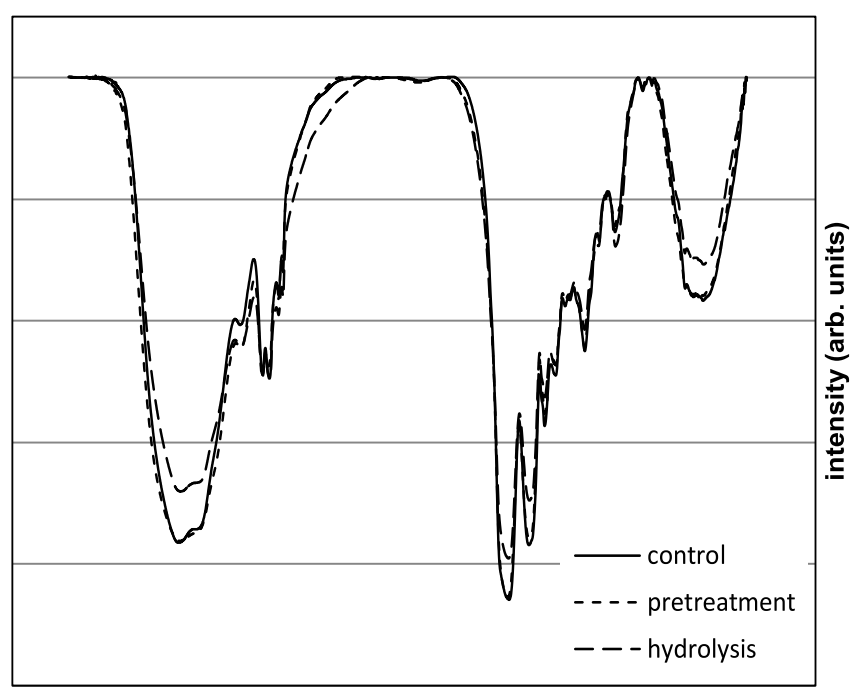

Figure 2. Substructural changes in the keratinous substrate after pretreatment and hydrolysis, compared with the native chicken feathers

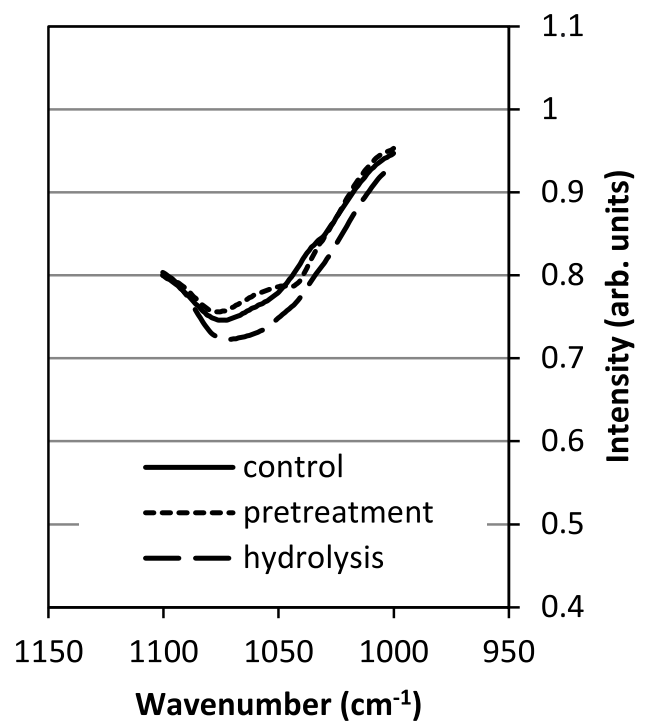

Figure 3. Close-up of the FITR spectrum of the signal from thioester residues at $1040 \mathrm{~cm}^{-1}$

The FTIR spectra of native, pretreated and hydrolyzed feathers exhibited minor changes, as no significant alterations in the chemical structure occurred in the characteristic regions of amide A $\left(3282 \mathrm{~cm}^{-1}\right)$ and amides I-III $\left(1600-1200 \mathrm{~cm}^{-1}\right)$. The signal of amide I band between 1600 and $1700 \mathrm{~cm}^{-1}$,sensitive to secondary structure of proteins, was resolved into Gauss-shaped components and their respective content was calculated (Tab. 5). It was shown that variation in the proportion between $\alpha$-helix and $\beta$-sheet did not exceed $3 \%$.

The sulphitolytic pretreatment caused a part of disordered structures to shift into other structures, which were in turn reduced during hydrolysis. This may suggest thatthe applied step of enzymatic hydrolysis involved liberation of intact keratin fibers and may be applied as an effective way of keratin fiber extraction.

\section{Amino acid composition of feather hydrolysates}

Feather degradation by a proteolytic preparation from B. cereus PCM2849 led to accumulation of free amino acids and soluble proteins at a significant concentration $(1.88 \%)$. The action of proteolytic enzymes resulted in
Table 5. Proportion of feather keratin substructures at respective stages of the experiment

\begin{tabular}{|l|c|c|c|}
\hline & $\begin{array}{c}\text { Band } \\
\text { position } \\
{\left[\mathrm{cm}^{-1}\right]}\end{array}$ & $\begin{array}{c}\text { Band } \\
\text { assignment }\end{array}$ & $\begin{array}{c}\text { Content } \\
{[\%]}\end{array}$ \\
\hline Untreated feathers & 1620 & $\beta$-sheet & 15.7 \\
& 1651 & a-helix & 45.3 \\
& 1673 & disordered & 4.4 \\
& 1696 & other & 34.6 \\
\hline Pretreatedsubstrate & 1621 & $\beta$-sheet & 14.5 \\
& 1651 & a-helix & 43.6 \\
& 1673 & disordered & 2.4 \\
& 1694 & other & 39.6 \\
\hline Hydrolysate & 1621 & $\beta$-sheet & 16.0 \\
& 1651 & a-helix & 44.0 \\
& 1672 & disordered & 3.2 \\
& 1694 & other & 36.8 \\
\hline
\end{tabular}

Table 6. Amino acid composition of the obtained feather hydrolysate

\begin{tabular}{|c|c|}
\hline Amino acid & $\mathrm{g} \mathrm{kg}^{-}$ \\
\hline \multicolumn{2}{|l|}{ non-essential } \\
\hline Ala & 3.22 \\
\hline Arg & 3.94 \\
\hline Asp & 5.02 \\
\hline Glu & 9.21 \\
\hline Gly & 6.06 \\
\hline Pro & 9.12 \\
\hline Ser & 7.08 \\
\hline \multicolumn{2}{|l|}{ essential } \\
\hline His & 0.60 \\
\hline Ile & 3.04 \\
\hline Leu & 5.88 \\
\hline Lys & 1.90 \\
\hline Met & 2.39 \\
\hline Cys & 0.15 \\
\hline Phe & 4.29 \\
\hline Tyr & 1.94 \\
\hline Thr & 2.65 \\
\hline Trp & 0.27 \\
\hline Val & 5.15 \\
\hline
\end{tabular}

the release of free amino acids to a different extent, as presented in Table 6. Glutamic acid $\left(9.21 \mathrm{~g} \mathrm{~kg}^{-1}\right)$ and proline $\left(9.12 \mathrm{~g} \mathrm{~kg}^{-1}\right)$ were detected at the highest concentration. Additionally, the hydrolyzed samples were rich in serine $\left(7.08 \mathrm{~g} \mathrm{~kg}^{-1}\right)$ and glycine $\left(6.06 \mathrm{~g} \mathrm{~kg}^{-1}\right)$. Moreover, the presence of leucine $\left(5.88 \mathrm{~g} \mathrm{~kg}^{-1}\right)$, valine $\left(5.15 \mathrm{~g} \mathrm{~kg}^{-1}\right)$ phenylalanine $\left(4.29 \mathrm{~g} \mathrm{~kg}^{-1}\right)$ and isoleucine (3.04 $\left.\mathrm{g} \mathrm{kg}^{-1}\right)$, representing essential and branched-chain amino acids, was confirmed.

Sangali and Brandelli ${ }^{26}$ investigated the amino acid composition of feather hydrolysates. Similarly, glutamate residues (containing glutamic acid and glutamine) and serine have been described as main products of feather hydrolysis. However, the concentration of proline was significantly lower, in comparison to own study.

In the work of Laba et al. ${ }^{23}$ feather hydrolysates obtained in cultures of K. rhizophila PCM 2931, were generally rich in phenylalanine $\left(50.0 \mu \mathrm{g} \mathrm{ml}^{-1}\right)$, histidine $\left(38.2 \mu \mathrm{g} \mathrm{ml}^{-1}\right)$ and arginine $\left(29.2 \mu \mathrm{g} \mathrm{ml}^{-1}\right)$. The lack of correspondence between presented research and own studies may pointed to differences between microbial breakdown of keratin and purely enzymatic hydrolysis, as well as diversity in enzymatic properties of each bacterial strain. 


\section{CONCLUSIONS}

Crude concentrated protease of B. cereus PCM 2849 was applied in order to decompose chicken feather waste. The process was optimized a Box-Behnken design and the impact of feather content, temperature and sulphite concentration during substrate pretreatment were evaluated. The highest influence on the final amino acids concentration in the reaction mixtures was exerted by reaction temperature, represented by both, quadratic and linear coefficients. As a result, efficient hydrolysis of feathers in optimal conditions, determined in the model (temperature $44.4^{\circ} \mathrm{C}$, feathers $4.7 \%$ and treatment with $25.3 \mathrm{mM}$ sulphite), was performed. Amino acids concentration and composition in the resultant hydrolysate were established. Consequently, significant amount of glutamic acid $\left(9.21 \mathrm{~g} \cdot \mathrm{kg}^{-1}\right)$, proline $\left(9.12 \mathrm{~g} \cdot \mathrm{kg}^{-1}\right)$ and branched-chain amino acids was detected. Additionally, the presence of thioester residues, revealed by the FTIR analysis, confirmed sulphitolysis of disulphide bonds in feather keratin. The conversion of feather waste into rich in amino acid hydrolysate could be an efficient way of feather waste management. The application of bacterial keratinases in keratin waste hydrolysis is not only economically and eco-friendly but also allows for an effective management of post-slaughter waste.

\section{ACKNOWLEDGMENTS}

Publication supported by Wroclaw Centre of Biotechnology, programme The Leading National Research Centre (KNOW) for years 2014-2018.

\section{LITERATURE CITED}

1. Lasekan, A., Bakar, F.A. \& Hashim, D.(2013). Potential of chicken by-products as sources of useful biological resources. Waste Manage.33(3), 552-565. https://doi.org/10.1016/j. wasman.2012.08.001

2. FAO. 2019. Meat Market Review, March 2019. Rome. Retrieved April 07, 2019, from http://www.fao.org/poultry-production-products/en/

3. Paul, T., Halder, S.K., Das, A., Bera, S., Maity, C., Mandal, A., Das, P.S., Das Mohapatra, P.K., Pati, B.R. \& Mondal, K.C. (2013). Exploitation of chicken feather waste as a plant growth promoting agent using keratinase producing novel isolate Paenibacillus woosongensis TKB2. Biocatal. Agric. Biotechnol. 2(4), 50-57. https://doi.org/10.1016/j.bcab.2012.10.001.

4. Huda, S. \& Yang, Y. (2009). Feather fiber reinforced light-weight composites with good acoustic properties. $J$. Polym. Environ. 17(2), 131-142. https://doi.org/10.1007/s10924009-0130-2.

5. Skopińska-Wiśniewska, J. (2013). Keratin in medicine and tissue engineering [in polish]. Polimery $W .58,2$. DOI: dx.doi. org/10.14314/polimery.2013.100.

6. Khosa, M.A., Wu, J. \& Ullah, A. (2013). Chemical modification, characterization, and application of chicken feathers as novel biosorbents. RSC $A d v$. 3(43), 20800-20810. https://doi. org/10.1039/C3RA43787F.

7. Gupta, R. \& Ramnani, P. (2006). Microbial keratinases and their prospective applications: an overview. Appl. Microbiol. Biotech. 70(1), 21-33. https://doi.org/10.1007/s00253-005-0239-8.

8. Brandelli, A. (2008). Bacterial Keratinases: Useful enzymes for bioprocessing agroindustrial wastes and beyond. Food and Bioprocess Tech. 1(2), 105-116. https://doi.org/10.1007/s11947-007-0025-y.

9. Gessesse, A., Hatti-Kaul, R., Gashe, B.A. \& Mattiasson, B.(2003). Novel alkaline proteases from alkaliphilic bacteria grown on chicken feather. Enzyme and Microbial Technology. 32(5), 519-524. https://doi.org/10.1016/S0141-0229(02)00324-1.

10. Suntornsuk, W. \& Suntornsuk, L. (2003). Feather degradation by Bacillus sp. FK 46 in submerged cultivation. Biores. Technol. 86(3), 239-243. https://doi.org/10.1016/S09608524(02)00177-3.

11. Yamamura, S., Morita, Y., Hasan, Q., Yokoyama, K. \& Tamiya, E. (2002). Keratin degradation: a cooperative action of two enzymes from Stenotrophomonas sp. Biochem. Biophys. Res. Communic. 294, 1138-1143.

12. Kumar, A.G., Swarnalatha, S., Gayathri, S., Nagesh, N. \& Sekaran, G. (2007). Characterization of an alkaline active - thiol forming extracellular serine keratinase by the newly isolated Bacillus pumilus. J. Appl. Microbiol. 104, 411-419. DOI: 10.1111/j.1365-2672.2007.03564.x.

13. Cortezi, M., Cilli, E.M. \& Contiero, J. (2008). Bacillus amyloliquefaciens: A new Keratinolytic Feather-degrading Bacteria. Current Trends in Biotechnol. Pharmacy. 2(1), 170-177.

14. Fakhfakh, N., Ktari, N. Haddar, A., Mnif, I.H., Dahmen, I. \& Nasri, M. (2011). Total solubilisation of the chicken feathers by fermentation with a keratinolytic bacterium, Bacillus pumilus A1, and the production of protein hydrolysate with high antioxidative activity. Process Biochemistry. 46(9), 1731-1737.

15. Daroit, D.J., Corrêa, A.P.F. \& Brandelli, A. (2011). Production of keratinolytic proteases through bioconversion of feather meal by the Amazonian bacterium Bacillus sp. P45. Internat. Biodeterior. \& Biodegrad. 65 (1), 45-51. doi:10.1016/j. ibiod.2010.04.014.

16. Choi, M.J. \& Nelson, P.V. (1996). Developing a slow-release nitrogen fertilizer from organic sources: II. Using poultry feathers. J. ASHS. 121(4), 634-638.

17. Gupta, R. \& Ramnani, P. (2006). Microbial keratinases and their prospective applications: an overview. Appl Microbiol and Biotech. 70(1), 21-33. https://doi.org/10.1007/s00253-005-0239-8.

18. Sun, S.W., Lin, Y.C., Weng, Y.M. \& Chen, M.J.(2006). Efficiency improvements on ninhydrin method for amino acid quantification. J. Food Compos. Anal. 19(2-3), 112-117. https:// doi.org/10.1016/j.jfca.2005.04.006.

19. Łaba, W. \& Szczekała, K.B. (2013). Keratinolytic proteases in biodegradation of pretreated feathers. Pol. J. Environ. Stud. 22(4), 1101-1109.

20. Liu, H.L., Lan, Y.W. \& Cheng, Y.C. (2004). Optimal production of sulphuric acid by Thiobacillus thiooxidans using response surface methodology. Process Biochem.39(12), 1953-1961. https://doi.org/10.1016/j.procbio.2003.09.018.

21. Eslahi, N., Hemmatinejad, N. \& Dadashian, F. (2013). From feather waste to valuable nanoparticles. Particul. Sci. Technol. 32(3), 242-250. https://doi.org/10.1080/02726351.201 3.851135 .

22. Kumar, M.D.J., Priya, P., Balasundari, N.S., Devi, N.G.S.D., Kalaichelvan, I.N.R.A. \& Kalaichelvan, P.T. (2012). Production and optimization of feather protein hydrolysate from Bacillus sp. MPTK6 and its antioxidant potential. Middle-East J. Sci. Res. 11(7), 900.907.

23. Łaba, W., Żarowska, B., Chorążyk, D., Pudło, A., Piegza, M., Kancelista, A. \& Kopeć, W. (2018). New keratinolytic bacteria in valorization of chicken feather waste. AMB Express. 8(1), 9. https://doi.org/10.1186/s13568-018-0538-y.

24. Eslahi, N., Dadashian, F. \& Nejad, N.H. (2013). An investigation on keratin extraction from wool and feather waste by enzymatic hydrolysis. Prep. Biochem. Biotech. 43(7), 624-648. https://doi.org/10.1080/10826068.2013.763826.

25. Paul, T., Das, A., Mandal, A., Halder, S.K., Dasmohapatra, P.K., Pati, B.R. \& Mondal, K.C. (2014). Valorization of chicken feather waste for concomitant production of keratinase, oligopeptides and essential amino acids under submerged fermentation by Paenibacillus woosongensis TKB2. Waste Biomass Valor. 5(1), 575-584. https://doi.org/10.1007/s12649-013-9267-2.

26. Sangali, S. \& Brandelli, A. (2000). Feather keratin hydrolysis by a Vibrio sp. strain kr2. J. Appl. Microbiol. 89(5), 735-743. https://doi.org/10.1046/j.1365-2672.2000.01173.x. 